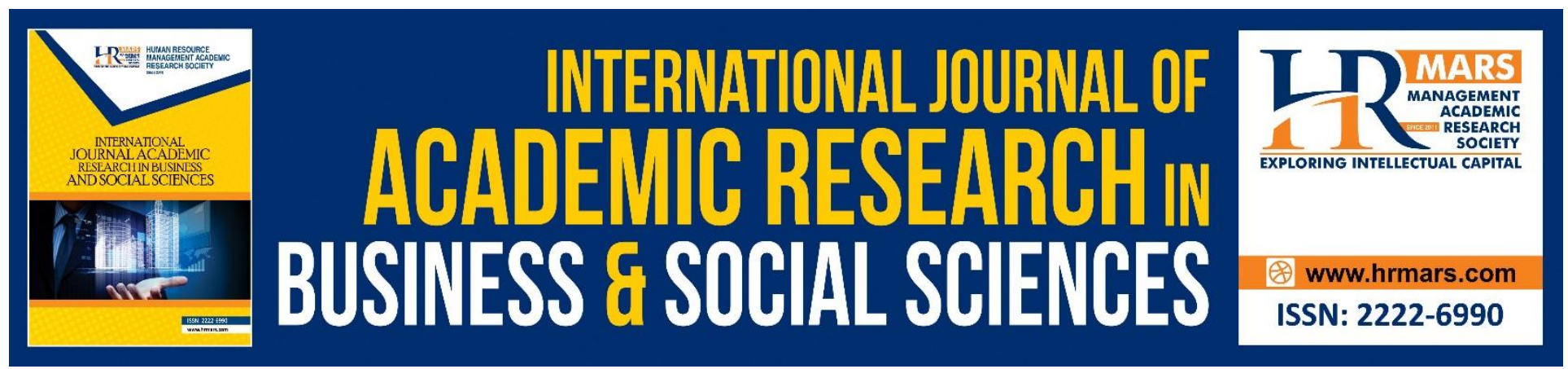

\title{
The Conflicts of Law in Islamic Banking Based on The Contracts Act 1950 and Evidence Act 1950: Malaysian Position
}

Muhammad Hafiz Mohd Shukri

To Link this Article: http://dx.doi.org/10.6007/IJARBSS/v10-i8/7660

DOI:10.6007/IJARBSS/v10-i8/7660

Received: 11 May 2020, Revised: 14 June 2020, Accepted: 22 July 2020

Published Online: 30 August 2020

In-Text Citation: (Shukri, 2020)

To Cite this Article: Shukri, M. H. M. (2020). The Conflicts of Law in Islamic Banking Based on The Contracts Act 1950 and Evidence Act 1950: Malaysian Position. International Journal of Academic Research in Business and Social Sciences. 10(8), 907-916.

Copyright: (C) 2020 The Author(s)

Published by Human Resource Management Academic Research Society (www.hrmars.com)

This article is published under the Creative Commons Attribution (CC BY 4.0) license. Anyone may reproduce, distribute, translate and create derivative works of this article (for both commercial and non-commercial purposes), subject to full attribution to the original publication and authors. The full terms of this license may be seen at: http://creativecommons.org/licences/by/4.0/legalcode

Vol. 10, No. 8, 2020, Pg. 907 - 916

http://hrmars.com/index.php/pages/detail/IJARBSS

JOURNAL HOMEPAGE

Full Terms \& Conditions of access and use can be found at http://hrmars.com/index.php/pages/detail/publication-ethics 


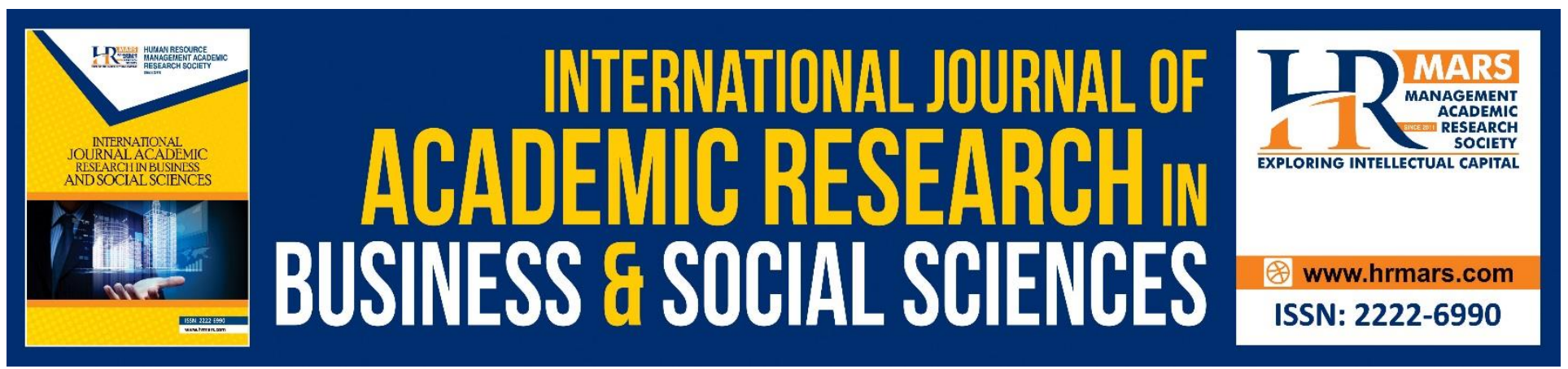

\title{
The Conflicts of Law in Islamic Banking Based on The Contracts Act 1950 and Evidence Act 1950: Malaysian Position
}

\author{
Muhammad Hafiz Mohd Shukri \\ Faculty of Economics and Business, Universiti Malaysia Sarawak, 94300 Kota Samarahan \\ Sarawak, Malaysia \\ Email: msmhafiz@unimas.my
}

\begin{abstract}
In order to maintain and uphold the institution of Islamic banking for future generations, it is vital to resolve potential conflicts that are faced by the Islamic banking sector. Malaysia is currently facing legislative conflicts between Islamic law and civil law, even after more than 30 years since the establishment of Islamic banking. Several court cases have proven that there are many conflicting issues in the Malaysian Islamic banking sector, which have posed a challenge to the Islamic financial system in Malaysia. This article aims to construct a harmonized legal framework between Islamic law and civil law in regulating the industry of Islamic banking, particularly through the enforcement of the Contracts Act 1950 and the Evidence Act 1950. The type of research carried out for the purpose of this paper is doctrinal legal research. The data sources were gathered and analysed using content analysis and critical analysis methods. The results showed that there are some statutory provisions in the abovementioned statutes which are not compatible with the principles of Islamic banking. As such, several recommendations have been suggested in order to harmonize the legal conflicts as they occur in the statutory provisions. Lastly, the outcomes of this research are expected to assist the harmonization process of legislation together with the intention of facilitating the development of the Islamic banking industry in Malaysia.
\end{abstract}

Keywords: Contracts Act 1950, Evidence Act 1950, Islamic Financial System, Legislation, Legislative Conflict.

\section{Introduction}

It is an undeniable fact that the exact period of the introduction of Islamic banking is not traceable since different sources have indicated different periods of its origin (Iqbal \& Mirakhor, 2007). Nevertheless, the most important thing which has been decided by nearly all Muslim scholars is the fact that Islamic banking dates back to the period of Prophet Muhammad SAW. In addition, some researchers claimed that even though banks did not exist during the period of Prophet Muhammad 
INTERNATIONAL JOURNAL OF ACADEMIC RESEARCH IN BUSINESS AND SOCIAL SCIENCES Vol. 10, No. 8, 2020, E-ISSN: 2222-6990 @ 2020 HRMARS

SAW, it is important to note that financial instruments were a part of commercial life, and usury had also been prohibited during this period (Bjorklund \& Lundstrom, 2004).

The Islamic financial system depends on religious substance, which is different from typical or conventional banking. Some scholars claim that due to its basis in Islam, Islamic finance may represent a better option (Mansour et al. 2015). Whatever it is, it keeps growing at a constant rate, and has demonstrated unprecedented development over the last two decades, despite the inconsistency of existing legal frameworks and business routines. The volume of Islamic finance resources has already reached US $\$ 1,460$ billion, with operations in more than 50 countries by the end of 2012 (Hanif, 2014).

In comparison, Malaysia is a unique country as it practices a dual banking system. The context of a dual banking system refers to the implementation of conventional banking and Islamic banking at the same time. According to the annual report published by the Central Bank of Malaysia, Malaysia was the first country to apply a dual banking system in which an Islamic banking system applies concurrently with a conventional banking system (Central Bank of Malaysia, 1993).

The first legal development in Islamic banking commenced in 1983 with the introduction of the Islamic Banking Act. Currently, Malaysia is viewed not only as a leader in Islamic banking, but as an Islamic finance powerhouse. The introduction of Islamic finance in Malaysia has been backed by firmly founded financial institutional structures and a solid regulatory framework (Lo \& Leow, 2014). Hence, it is crystal clear that the legal framework of the Islamic banking system is the backbone of the Islamic banking industry in this country. It is therefore of paramount importance to explore the more evident challenges to the legal framework of the country.

Legislative conflicts are among the existing challenges which need to be solved accordingly. This contention has been derived from the establishment of the Law Harmonization Committee at the Central Bank of Malaysia. This is because the legislation which is applicable to the Islamic banking sector in Malaysia is derived from common law, which is not similar to the real context of Islamic law and banking. Islamic banking is entirely derived from Islamic principles. However, in terms of its application in Malaysia, somehow the court is compelled to implement civil law, which is substantially inconsistent with Islamic law. Theoretically and practically speaking, the Islamic banking sector should be Islamic from all facets, only then shall the true nature of Islamic banking be reflected.

Therefore, it is crucial for researcher to identify the existing legislative conflicts in detail by analyzing the statutory provisions which have been invoked in the reported Islamic banking cases. Otherwise, the development and well-being of the Islamic banking sector in Malaysia might be affected. For the purpose of conducting this research, only two specific Acts of Parliament will be selected, which are the Contracts Act 1950 and the Evidence Act 1950. These statutes are also indirectly applicable to Islamic banking transactions in Malaysia.

Hence, the main objective of this research is to construct a harmonized legal framework between Islamic law and civil law in regulating the industry of Islamic banking in Malaysia, particularly based on the legal provisions of Contracts Act 1950 and the Evidence Act 1950. 
INTERNATIONAL JOURNAL OF ACADEMIC RESEARCH IN BUSINESS AND SOCIAL SCIENCES Vol. 10, No. 8, 2020, E-ISSN: 2222-6990 @ 2020 HRMARS

\section{Literature Review}

Generally, there is a vast amount of literature available for research in Islamic banking. However, the researcher discovered that there were only a few studies and writings that explored the current research topic. Most of these writers discussed the general history of Islamic banking across the world and in Malaysia, without an in-depth examination of the legal aspects and existing legislative conflicts within the Islamic banking system. In addition, it was found that only a few research outputs criticized or discussed the judgments of reported Islamic banking cases in Malaysia. Be that as it may, a large portion of these written works are centered on either the rise of the Islamic banking system or the financial products offered by Islamic banks. However, the legal issues of Malaysian Islamic banking areas are rarely discussed.

The key selection criteria for Islamic banks have been identified, such as quick and proficient services, status, as well as customer privacy (Erol \& El-Bdour, 1990). Surprisingly, this study also found that the religious factor was not an essential basis for preference of Islamic banks over others. In contrast to this statement, it has been observed that perceptions about Islamic banking are also significantly influenced by a religious perspective (Haque et al. 2009). Although the literature is valuable in the context of Islamic banking expansion, it has failed to discuss Islamic banking from a legal perspective and is focused more on principles of economics and finance.

It is interesting to note that the clarification of Islamic law is left to Islamic schools of thought, which have developed in several different Muslim societies across the world. The absence of standardization among these schools of thought makes it challenging for Western policymakers to comprehend the notion of Islamic finance (Karbharil, 2004). Meanwhile, the most crucial issue for Islamic banking are the differences in terms of understanding what is and is not Islamic banking (Ainley, 1997). As a solution to this problem, other researcher has analysed the standardization of Islamic financial law as well its importance for Islamic banking industry (Ercanbrack 2020$)$. However, again, those discussions have failed to propose any specific solutions to overcome the legal conflicts as found in the legal framework of Islamic banking law in Malaysia.

Islamic banks shall comply with Islamic law in all their dealings. Furthermore, Islamic banks also must comply with the laws of the jurisdiction in which they operate. On this point, one of the crucial issues towards building a sustainable sector of Islamic finance is the development of legal framework (Hassan, 2017). Hence, conducting research on the existing legislative conflicts is also among one of these endeavours.

In addition, the other researcher describes the starting point of Islamic banking in the country. It was observed in his work that the landmark that led to the establishment of Islamic banking legal framework was the enactment of the Islamic Banking Act 1983. He was of the view that the statute then related to conventional banking, which was the Banking Act 1973, was not suitable to apply to an Islamic bank; as such, the Islamic Banking Act 1983 was enacted (Thani, 2003).

Besides that, Halsbury's Laws of Malaysia also comprehensively discusses the Islamic Banking Act 1983 and the legal provisions which are applicable to the Islamic law of banking. However, such discussions in the aforementioned literature are merely descriptive, with the authors failing to 
INTERNATIONAL JOURNAL OF ACADEMIC RESEARCH IN BUSINESS AND SOCIAL SCIENCES Vol. 10, No. 8, 2020, E-ISSN: 2222-6990 @ 2020 HRMARS

discuss the practical problems faced by Islamic banking in Malaysia. Due to the change of laws applicable to Islamic banking such as the introduction of the new Islamic Financial Services Act 2013, some of the discourse in these books has thus become obsolete.

On the other hand, the book "Islamic Banking and Takaful" classifies the legal framework related to Islamic banking in Malaysia into two types, which are regulatory laws and laws on transactions (Hassan, 2011). The legislations under the category of regulatory laws are as follows: the Central Bank of Malaysia Act 2009, the Islamic Banking Act 1983, the Banking and Financial Institutions Act 1989, the Takaful Act 1984, and the Government Investment Act 1983. On the other hand, the identified legislations under laws on transactions are the National Land Code 1965, the Companies Act 1965, the Contracts Act 1950, as well as procedural laws. After 30 years of its application, the Islamic Banking Act 1983 was abolished and replaced by the Islamic Financial Services Act 2013. The book also discusses reported court cases on Islamic banking in Malaysia. For instance, after discussing the facts and judgment of the case of Dato' Hj. Nik Mahmud bin Daud v. Bank Islam Malaysia Bhd (1998) $3 \mathrm{CL}$ 605, the author commented that it was evident from the judgment of this case that there are conflicts arising between Islamic financial transactions and other general laws applicable in Malaysia. As such, it is proven that there are several legislative conflicts within the Islamic banking sector. After scrutinizing the material facts of Tinta Press Sdn Bhd v. Bank Islam Malaysia Bhd (1987) CLJ 396, the author concluded that the judge in this case failed to appreciate the contract of leasing, and in deciding this case, the judge made no reference to the Islamic law of transactions and Islamic banking system. Thus, it is crucial to do in-depth research on this area to find out the specific legislative conflicts within the Islamic banking system. Obviously, harmonization of the law could be the answer to the legislative conflicts faced by Islamic banking. Revision of the applicable and relevant laws with regards to Islamic banking in Malaysia is therefore necessary. Bank Negara has also taken steps towards doing this by recently establishing committees such as the Law Harmonisation Committee on Islamic Finance in 2010. It is hoped that the outcome of this research shall be referred to by the policymakers, specifically the Malaysian legislative body in formulating effective policies by achieving uniformity in Malaysian law with regards to Islamic finance.

\section{Research Methodology}

In this research, the exploratory and descriptive approach was applied to express a summary of the available law for Islamic banking in Malaysia. Meanwhile, the analytical approach was applied to examine the legal provisions raised through the court cases, as well as to examine the provisions under the Contracts Act 1950 and the Evidence Act 1950 by referring to the judges' decisions in order to identify the potential legal conflicts. Moreover, substantial reference has been made on the related data which are accessible through journals and law textbooks.

\section{Results \& Discussion}

Generally, the Contracts Act 1950 is an Act related to contracts as stated in its preamble. It is the general law which governs and provides rules for the agreement between the contracting parties in Malaysia. Nevertheless, there are also other comprehensive codes which have been developed to regulate contractual relationship between parties in Malaysian commercial transactions, parallel to the Contracts Act 1950. For instance, there is the Partnership Act 1961 which governs the relationship and agreements made between partners that form partnerships, the Hire Purchase Act 1967 which 
INTERNATIONAL JOURNAL OF ACADEMIC RESEARCH IN BUSINESS AND SOCIAL SCIENCES Vol. 10, No. 8, 2020, E-ISSN: 2222-6990 @ 2020 HRMARS

describes the rules related to hire-purchase agreements, the Sales of Goods Act 1967 that deals with the requirements under sale of goods, and the Companies Act 1965 that deals with the contractual agreement involved in the formation of companies. In other words, all of the above legislation is relevant with regards to the specific rules and regulations in which a valid contract shall be enforced (Yussoff, 2009).

The principle of unlawful consideration is related to Section 24 of the Contracts Act 1950, whereby it lists several factors under which the consideration and objects of contract are considered lawful and unlawful. The full provision of the above section has been quoted as below:

"The consideration or object of an agreement is lawful unless - a) it is forbidden by a law; b) it is of such nature that, if permitted, it would defeat any law; c) it is fraudulent; $d$ ) it involves or implies injury to the person or property of another; or e) the court regards it as immoral, or opposed to public policy. In each of the above cases, the consideration or object of an agreement is said to be unlawful. Every agreement of which the object or consideration is unlawful is void".

In the case of Tan Sri Abdul Khalid Ibrahim v. Bank Islam Malaysia Bhd \& Another (2010) 4 CLJ 388, the plaintiff claimed that the Bai' Bithaman Ajil (BBA) agreement which was granted by the defendant was against the law or public policy under Section 24(e) of the Contracts Act 1950, and therefore was not enforceable. According to the plaintiff, this was due to the fact that the BBA agreement was against Islamic law. Among the contentions which were put forward by the plaintiff in order to support his argument are as follows:

1. The BBA agreement either read together with the security documents or even independently means that it shall be considered as a financial plan and not a sale transaction as it ought to be.

2. The BBA agreement turns into bay' al-inah as the reading of the agreement shows that there is a relation between the Asset Purchase Agreement (APA) and Asset Sale Agreement (ASA).

3. The discarding of the pledged Guthrie shares by the bank without informing the plaintiff conflicts with Islamic principles, which are identified as al-rahnu since it needs the consent of the pledgee.

The court held that even though the plaintiff argued that there was non-compliance of certain Islamic rules, it important to note that Islamic teachings uphold the rule of fulfilling the contractual obligations entered between the parties.

On the other hand, in the case of Arab-Malaysian Merchant Bank Berhad v. Silver Concept Sdn Bhd (2005) $5 \mathrm{MLJ} 210$, one of the arguments submitted by the defendant is that the agreements made between him and the plaintiff were contrary to public policy since they had deceived the public and had been immoral as stipulated under Section 24 of the Contracts Act 1950. As such, according to the defendant, the agreement was unlawful and void. Specifically, the defendant claimed that the BBA agreement and the al-wujuh agreement were illegal, null and void. The defendant also alleged that the al-wujuh agreement was a loan contract with a fixed interest rate payable by the defendant, and 
INTERNATIONAL JOURNAL OF ACADEMIC RESEARCH IN BUSINESS AND SOCIAL SCIENCES Vol. 10, No. 8, 2020, E-ISSN: 2222-6990 @ 2020 HRMARS

not a sale agreement. However, the court in this particular case rejected the above argument whereby the judge mentioned in his judgment the following:

"I reject any argument that injects the argument that it is not permissible to buy on credit when there is mutual consent. Even Prophet Muhammad had occasion to buy some grain from a Jew to be paid at a specific time with his coat of mail as security. I am unable to acquiesce to any argument to that, just because a larger sum is agreed to be paid increasing the price due to lapse of time. I therefore reject the argument of the defendant that just because the defendant pays more than what was needed to buy the impugned property, such sum (profit) must be interest per se."

In the light of the Islamic law perspective, it would be paramount to include the phrase 'contrary to Islamic law for Islamic banking and finance cases' based on Section 24 of the Contracts Act 1950. Consequently, it would clearly guarantee that if there is anything contrary to the principles of Shariah, the contract would automatically be void. The majority of Muslim scholars are of the view that the prohibition of any contract means that it is invalid, and at the same time the parties engaged in such contracts commit a sin (Zuhayli, 2002).

Meanwhile, the Evidence Act 1950 is one of the most important Acts of Parliament that needs to be referred to in order to prove Islamic banking cases in court. In sum, it is the statutory code in which the principles of evidence are found in Malaysia as stated in the preamble of the Evidence Act 1950. Before going into further detail on the relevant provisions of the Evidence Act 1950 which have been applied in court cases of Islamic banking, it is useful to first understand the meaning of 'evidence.' Section 2 of the Evidence Act 1950 defines 'evidence' as to 'include oral evidence and documentary evidence'. On the other hand, under Section 3 of the Evidence Act 1950, 'oral evidence' is defined as 'all statements which the court permits or requires to be made before it by witnesses in relation to matters of fact under inquiry'. Under the similar provision, 'documentary evidence' means 'all documents produced for the inspection of the court'.

Expert evidence is generally described as the testimony of a person skilled in a certain field. From the Islamic point of view, the admission of expert opinion is permissible. Allah SWT mentioned in the following verse of the Al-Quran, which means: 'And we sent not before you except men to whom we revealed (Our message). So, ask the people of the message if you do not know' (Basmeih, 2013).

Based on Article 1689 of the Mejelle, it is obvious that opinions of skilled persons are acceptable as authentic testimony, even if they do not use the word syahadah or testimony (Tyser, 2001).

The issue in relation to Section 45 of the Evidence Act 1950 does not exist within the section itself. However, it concerns the interpretation of the section. The main issue here is whether or not the Malaysian court shall consider Islamic law to fall within the ambit of 'foreign law' based on Section 45 of the Evidence Act 1950.

Under Section 45 of the Act, expert opinions are only relevant upon a point of foreign law, science, art, identity of handwriting, or finger impressions. Another issue is that Islamic law is categorized by the Malaysian court as local law, not foreign law. In the locus classicus of Ramah binti Taat v. Laton 
INTERNATIONAL JOURNAL OF ACADEMIC RESEARCH IN BUSINESS AND SOCIAL SCIENCES Vol. 10, No. 8, 2020, E-ISSN: 2222-6990 @ 2020 HRMARS

binti Malim Sultan (1927) 6 FMSLR 128, Thorne J. held that Islamic law is not foreign law and it is the law of the land. Therefore, the court must take judicial notice of it and must propound the law. From the above court decision, it indirectly shows that expert evidence is not admissible in court cases which are related to Islamic law due to the reason that it is not a foreign law as stated under Section 45 of the Evidence Act 1950. Besides that, the approach taken by the learned judge in the above case is one of the common law approaches which contradict Islamic law, since the evidence from other Muslim experts is allowed and permissible under Islamic law (Marican, 2002). It is also paramount to note that the decision in the above-mentioned case was a majority decision.

On the other hand, the learned judge in the case of Dalip Kaur v. Pegawai Polis Daerah Bukit Mertajam (1992) 1 MLJ 1 viewed that in order to determine issues on apostasy, it is required to consider the opinions given by expert Muslim scholars in the related area of knowledge. As such, it proves that the testimony of Muslim experts is important in cases concerning Islamic law.

However, it can be seen that the approach taken by the Malaysian judges on this matter has been quite inconsistent. In the case of Commissioners for Religious Affairs Terengganu \& Ors v. Tengku Mariam (1971) $1 \mathrm{MLJ}$ 265, there was an issue pertaining to waqf. Initially, the parties involved had consulted the Mufti to decide on whether waqf made by Tengku Chik for the benefit of his family was legal or not. Later on, the Mufti approved the legality of such waqf. Unfortunately, the learned judge in the above case refused to accept the opinion given by the Mufti.

Therefore, it seems that the opinion of Muslim experts with regards to Islamic law of banking and finance is not consistently admissible in the Malaysian court based on the above court decisions. In reality, the opinions of the Syariah Advisory Council (SAC) may be crucial to determine the legality of certain matters in Islamic banking cases. The issue at hand could be solved by amending the Evidence Act 1950 in such a way so as to insert Islamic banking law as an area in which expert opinion could be consulted by the court before arriving at a verdict, and at the same time avoid any inconsistency in terms of accepting the evidence whenever the Malaysian courts are faced with this area of law.

The above rule of law has been enacted under Sections 91 and 92 of the Evidence Act 1950, whereby it signifies that once a contract or an agreement is made in writing, it reveals the intention of the contracting parties, and extrinsic evidence contradictory to the written terms of the contract cannot be varied, added or contradicted with the terms of the contract. Meanwhile, based on Section 92 of the Evidence Act 1950, there are six exceptions to the principle of parol evidence, which are, proof of absence of fraud or misrepresentation, existence of a collateral agreement or condition precedent or distinct subsequent condition or proof or usage or custom or language in the context of the document.

In the case of Tahan Steel Corporation Sdn Bhd v. Bank Islam Malaysia Bhd (2004) 6 CL 25, the court has discussed the effect of the subsection (a) to Section 92 of the Evidence Act 1950. The learned judge opined that this particular section provides certain exceptions where, for instance, any fact may be proved which would invalidate a document such as fraud, illegality, intimidation, want of due execution, lack of capacity of any contracting party, failure of consideration and finally, mistake of law or fact. 
The relevant issue in the above case was regarding the legality of bringing a variation to an agreement made between the plaintiff and defendant. The plaintiff alleged the substitution of the loan condition for a local bond issue was valid, by holding the view that they were entitled to it even without the express written consent of the defendant, and that the defendant by mere omission had agreed to the substitution of the loan condition for a local bond issue. As a result, the court had to decide on the issue of whether or not an express written agreement by a mere omission on the part of the defendant could be held as constituting agreement to a variation of the contract between the parties. By referring to Section 91 of the Evidence Act 1950 and the related case law, the learned judge in the above case made the following decision which indirectly rejected the argument made by the defendant:

"I am not willing to condone the plaintiff's relaxed attitude in relation to the variation of a condition precedent of the written agreement between the plaintiff and the defendant. A party is not entitled to unilaterally vary a contract and then found a cause of action for breach of contract against the other party based on that unilateral variation. This goes against the prevailing law in this country."

Meanwhile in relation to the contradiction of any agreement involving Islamic financial institutions and Islamic law of banking, Section 92 of the Evidence Act 1950 is silent on this matter as it is not included as one of the exceptions to the parol evidence rule. Thus, it is recommended that Section 92 needs to be amended since it is very important to insert another new provision such as 'in Islamic banking contracts, any term which is contrary to Islamic principles would be an exception to the parol evidence rule'.

\section{Implication of Study}

The researcher hope that the outcomes of this research output will contribute to the harmonization process of legislation towards the construction of a beneficial legal system which encourages the growth of Islamic banking and finance as well as to fill the gaps in the literature on legislative conflict faced by Islamic banking in Malaysia. Consequently, it fulfils the objective of ensuring the efficient and smooth conduct of the Islamic finance sector. Indirectly, it gives the opportunity to the Malaysian legal framework to be positioned as the benchmark for Islamic finance transactions at the global stage.

\section{Conclusion}

It is evident that there are several legislative conflicts in terms of Islamic law and banking which need to be resolved principally based on the Contracts Act 1950 and the Evidence Act 1950. An efficient harmonization of laws is needed to enable the feasible growth of the Islamic finance sector in Malaysia. Therefore, the enactment of comprehensive legislation on Islamic banking would ensure that the applicable laws for Islamic banking are constantly in line with Islamic law.

The findings of this study will redound to the benefit of society in the sense that the proposed legal solution will be expected to be the law of choice for Islamic finance transaction based on its ability to address points of disputes concerning its solution from Shariah perspective in the courts of law. Additionally, the analysis of findings from this research will also provide new insights into the body 
INTERNATIONAL JOURNAL OF ACADEMIC RESEARCH IN BUSINESS AND SOCIAL SCIENCES

Vol. 10, No. 8, 2020, E-ISSN: 2222-6990 @ 2020 HRMARS

of legal knowledge particularly in the area of Islamic banking law which is to be utilized by the policy makers and academic community.

\section{Acknowledgements}

Financial support from the Ministry of Higher Education Malaysia through Research Acculturation Grant Scheme (RAGS) [Grant No: RAGS/SSI10(1)/1179/2014 (02)] is gratefully acknowledged.

\section{References}

Ainley, M. (1997). Under a veil of regulation. The Banker, 147(860), 73-74.

Basmeih, A. (2013). Tafsir Pimpinan Ar-Rahman Kepada Pengertian Al-Quran (30 Juz) - Mushaf Malaysia Rasm Uthmani. (4th ed.). DarulFikir.

Bjorklund, I., \& Lundstrom, L. (2004). Islamic Banking: An Alternative System. Kristiantad University.

Central Bank of Malaysia. (1993). Annual Report. Central Bank of Malaysia.

Ercanbrack, J. (2020). The standardization of Islamic financial law: Lawmaking in modern financial markets. The American Journal of Comparative Law, 67(4), 825-860.

Erol, C., \& El-Bdour, R. (1990). Conventional and Islamic bank patronage behaviour of Jordanian customers. International Journal of Bank Marketing, 8(5), 25-35.

Hanif, M. (2014). Differences and similarities in Islamic and conventional banking. International Journal of Business and Social Sciences, 2(2), 166-175.

Haque, A., Osman, J., \& Ismail, A. Z. (2009). Factor influences selection of Islamic banking: A study on Malaysian customer preferences. American Journal of Applied Sciences, 6(5), 922-928.

Hassan, M. K., Mohd Yusof, R., \& Naiimi, N. (2017). Islamic banking sustainability: A review of literature and directions for future research. Emerging Markets Finance and Trade, 53(2), 440470.

Hassan, R. (2011). Islamic Banking and Takaful. Pearson Custom Publishing.

Iqbal, Z., \& Mirakhor, A. (2007). An Introduction to Islamic Finance, Theory and Practice. John Wiley \& Sons (Asia) Pte Ltd.

Karbharil, Y., Naser, K., \& Shahin, Z. (2004). Problems and challenges facing the Islamic banking system in the West: The case of the UK. Thunderbird International Business Review, 46(5), 521543.

Lo, C. W., \& Leow, C. S. (2014). Islamic banking in Malaysia: A sustainable growth of the consumer market. International Journal of Trade, Economics and Finance, 5(6), 526-529.

Mansour, W., Ben, J. K., \& Majdoub, J. (2015). How ethical is Islamic banking in the light of the objectives of Islamic law? Journal of Religious Ethics, 43, 51-77.

Marican, P. (2002). The Syariah/civil law dichotomy and its impact on the Malaysian legal system. IIUM Law Journal, 12(1), 251-252.

Thani, N. N., Abdullah, M. R., \& Hassan, M. H. (2003). Law and Practice of Islamic Banking and Finance. Sweet and Maxwell Asia.

Tyser, C. R., Demetriades, D. G., \& Effendi, I. H. (2001). The Mejelle: An English Translation of the Mejelle Al-Ahkam Al-'Adliyyah. The Other Press.

Yussoff, Y. (2009). General concept of Contracts Act 1950. Current Law Journal, 7, 37-44.

Zuhayli, W. (2002). Financial Transactions in Islamic Jurisprudence. Dar Al Fikr. 